\title{
Analisis Miskonsepsi Materi Sistem Peredaran Darah Manusia Tema 4 pada Siswa Kelas V SD
}

\author{
Mar'atul Izza*, Sukamti, Sri Estu Winahyu \\ Universitas Negeri Malang, Jl. Semarang No. 5 Malang, Jawa Timur, Indonesia \\ *Penulis korespondensi, Surel: maratulizza17@gmail.com
}

Paper received: 6-8-2021; revised: 20-8-2021; accepted: 28-8-2021

\begin{abstract}
This study aims to describe the material misconceptions about the human circulatory system in fifth grade students at SD Negeri 1 Sumberpasir. This study uses a qualitative approach with data collection through essay tests and interviews. The research subjects were fifth grade students. The results showed that there were still many students who had misconceptions about the concept of the human circulatory organ, the process of human blood circulation, human blood circulation disorders and how to maintain the health of the circulatory organ.
\end{abstract}

Keywords: misconception; human circulatory system

\begin{abstract}
Abstrak
Penelitian ini bertujuan untuk mendeskripsikan miskonsepsi materi sistem peredaran darah manusia pada siswa kelas V di SD Negeri 1 Sumberpasir. Penelitian ini menggunakan pendekatan kualitatif dengan pengumpulan data melalui tes esai dan wawancara. Subjek penelitian yaitu siswa kelas V. Hasil penelitian menunjukkan masih banyak siswa yang mengalami miskonsepsi pada konsep organ peredaran darah manusia, proses peredaran darah manusia, gangguan peredaran darah manusia dan cara memelihara kesehatan organ peredaran darah.
\end{abstract}

Kata kunci: miskonsepsi; sistem peredaran darah manusia

\section{Pendahuluan}

Konsep awal yang dimiliki oleh siswa berdasarkan pengalaman dan pengamatan dari lingkungan belum tentu sesuai dengan konsep yang dikemukakan oleh para ilmuwan, hal ini menyebabkan terjadinya miskonsepsi. Menurut Wisudawati dan Sulistyowati (2014) miskonsepsi merupakan konsep awal yang tidak sesuai dengan para ahli. Pendapat serupa dikemukakan oleh Sari (2018) yang menyatakan bahwa miskonsepsi adalah konsepsi atau gagasan yang tidak sesuai dengan konsepsi ilmiah yang dikemukakan oleh para ahli dalam suatu bidang tertentu.

Miskonsepsi dapat terjadi dikarenakan oleh beberapa faktor, baik faktor yang berasal dari diri siswa maupun faktor lainnya. Menurut Wardani (2017) yang menyatakan beberapa faktor penyebab kesalahan dalam pembelajaran IPA SD diantaranya yaitu usia anak yang masih berada pada tahap operasional konkret sudah harus mempelajari konsep-konsep abstrak dan belum optimalnya guru dalam upaya meningkatkan penguasaan konsep. . Faktor lain yang menyebabkan terjadinya miskonsepsi pada siswa juga bisa disebabkan oleh guru dan bahan ajar. Apabila guru mengalami miskonsepsi kemungkinan besar siswa akan menerima konsep yang salah dari guru.

Miskonsepsi menjadi salah satu permasalahan yang sering terjadi di dalam pembelajaran IPA. Muatan IPA di sekolah dasar dibagi ke dalam beberapa tema. Sistem peredaran darah menjadi salah satu materi dalam pembelajaran IPA di kelas $\mathrm{V}$ 
SD. Berdasarkan Permendikbud No 37 Tahun 2018 materi sistem peredaran darah yang dibahas pada kelas V SD yaitu mengenai organ peredaran darah dan fungsinya pada hewan dan manusia serta cara memelihara kesehatan organ peredaran darah manusia.

Di masa pandemi covid-19 saat ini, untuk sementara waktu pembelajaran dilakukan secara daring (dalam jaringan). Dengan keterbatasan sumber dan media pembelajaran, siswa dilatih untuk bisa belajar secara mandiri dengan bimbingan orang tua. Hal ini juga dapat menimbulkan adanya miskonsepsi dalam diri siswa, khususnya pada pembelajaran IPA. Siswa bisa saja menyimpulkan konsep yang kurang tepat apabila tidak mendapatkan pengalaman langsung dan penjelasan dari guru. Miskonsepsi yang terjadi dapat menyebabkan rendahnya hasil belajar dan memengaruhi pada pemahaman konsep yang lainnya.

Berdasarkan wawancara awal kepada guru kelas, diperoleh fakta bahwa siswa masih banyak yang belum memahami konsep peredaran darah manusia karena konsep pada sistem peredaran darah manusia cukup rumit. Pada pembelajaran daring saat ini, banyak materi yang tidak tersampaikan secara utuh termasuk materi sistem peredaran darah yang memiliki banyak konsep.

Penelitian terkait analisis miskonsepsi pada siswa mengenai materi sistem peredaran darah juga pernah dilakukan di berbagai jenjang pendidikan. Penelitian oleh Syarafina, dkk (2020) menunjukkan terjadinya miskonsepsi pada topik aktivitas jantung dan pembuluh darah. Terdapat 9,3\% siswa yang mengalami miskonsepsi pada materi aktivitas jantung, 22,7\% mengalami miskonsepsi terkait arteri pulmonalis, 38,2\% mengalami miskonsepsi terkait vena pulmonalis, 23,7 \% mengalami miskonsepsi terkait pembuluh nadi (arteri), dan 16,5\% mengalami miskonsepsi dalam membedakan arteri dan vena.

Penelitian ini berfokus pada materi sistem peredaran darah manusia. Penelitian ini bertujuan untuk mengetahui miskonsepsi pada konsep organ peredaran darah manusia, proses peredaran darah manusia, gangguan peredaran darah manusia dan cara memelihara kesehatan organ peredaran darah..

\section{Metode}

Metode yang digunakan dalam penelitian ini yaitu kualitatif. Subjek penelitian ini yaitu siswa kelas V SD Negeri 1 Sumberpasir. Teknik pengumpulan data yang digunakan yaitu tes, wawancara dan dokumentasi. Instrumen tes yang digunakan dalam penelitian ini yaitu tes diagnostik berupa soal esai tertulis sebanyak 10 butir soal yang telah divalidasi oleh ahli materi. Analisis data yang digunakan dalam penelitian ini yaitu reduksi data, penyajian data, penarikan kesimpulan dan verifikasi data. Pengecekan keabsahan data yang dilakukan yaitu validasi instrumen tes dan triangulasi teknik.

\section{Hasil dan Pembahasan}

\subsection{Hasil}

Pada konsep organ peredaran darah manusia terdapat 6 butir soal, yaitu soal nomor 16. Soal nomor 1 membahas mengenai fungsi ruang jantung. Soal nomor 2 mengenai hubungan paru-paru dengan jantung. Soal nomor 3, 4, dan 5 membahas mengenai ciri-ciri pembuluh nadi dan pembuluh balik dan soal nomor 6 mengenai hubungan aktivitas manusia dengan denyut nadi. Pada soal nomor 1 beberapa siswa menjawab otot yang paling tebal dimiliki oleh ruang 
serambi. Pada soal nomor 2 masih banyak siswa yang mengalami miskonsepsi dalam sub konsep hubungan organ paru-paru dengan jantung, beberapa siswa hanya menjelaskan peran paru-paru. Pada Soal nomor 3 banyak siswa yang memilih jawaban selain aliran. Pada butir soal nomor 4 sebagian siswa menjawab darah dalam pembuluh arteri paru-paru banyak mengandung karbondioksida karena dibutuhkan oleh manusia dan aliran darahnya ke jantung. Pada butir soal nomor 5 beberapa siswa yang menganggap bahwa denyutan pada tangan terasa karena melakukan aktivitas berat. Pada butir soal nomor 6, banyak siswa yang menjawab jawaban benar yaitu berlari, akan tetapi alasan yang diberikan tidak sesuai dengan konsep ilmiah.

Konsep proses peredaran darah manusia terdapat pada butir soal nomor 7 dan 8. Butir soal nomor 7 membahas mengenai proses peredaran darah besar dan nomor 8 mengenai proses peredaran darah kecil. Pada proses peredaran darah besar, beberapa siswa menganggap proses peredaran darah kecil juga termasuk dalam proses peredaran darah besar. Sedangkan pada proses peredaran darah kecil, beberapa siswa menjawab prosesnya dimulai dari paru-paru.

Pada konsep gangguan peredaran darah pada manusia juga ditemukan banyak miskonsepsi. Beberapa siswa sudah menjawab dengan jawaban yang tepat yaitu anemia, akan tetapi masih salah dalam menjelaskan faktor-faktor yang mengakibatkan penyakit tersebut.

Pada konsep cara memelihara kesehatan organ peredaran darah manusia. Beberapa siswa sudah hampir menjawab dengan benar, akan tetapi konsep yang dijelaskan kurang lengkap atau kurang ilmiah. Beberapa siswa hanya menjelaskan manfaat olahraga secara umum.

\subsection{Pembahasan}

Miskonsepsi siswa terhadap konsep organ peredaran darah manusia dapat diketahui dari soal nomor 1, 2, 3, 4, 5, dan 6. Hasil analisis dari jawaban siswa menunjukkan adanya miskonsepsi pada konsep organ peredaran darah. Konsep organ peredaran darah yang terdapat pada soal meliputi ruang jantung dan fungsinya, hubungan paru-paru dengan jantung, ciri-ciri pembuluh nadi dan pembuluh balik dan hubungan aktivitas manusia dengan denyut nadi.

Butir soal nomor 1 berisi sub konsep ruang jantung dan fungsinya pada manusia. Pada soal nomor 1 semua subjek penelitian mengalami miskonsepsi. Menurut Setiadi (2020) otot penyusun pada bilik lebih tebal daripada otot pada serambi. Hal ini disebabkan fungsi bilik jantung lebih berat yaitu untuk memompa darah keluar dari jantung ke seluruh bagian tubuh. Semua subjek masih kebingungan dalam menentukan ruang jantung yang memiliki otot paling tebal. Beberapa siswa memiliki konsep terbalik karena menganggap serambi yang berfungsi sebagai pemompa darah.

Pada sub konsep hubungan organ paru-paru dan jantung siswa yang mengalami miskonsepsi yaitu S1 dan S3. Kedua siswa tersebut memiliki jawaban yang hampir sama yaitu sebagai alat pernapasan. Akan tetapi mereka belum memahami bagaimana peran jantung dalam proses peredaran darah. Menurut Subekti (2017) paru-paru berperan dalam menyuplai oksigen ke dalam darah. S1 hanya memahami bahwa paru-paru berperan sebagai pernapasan makhluk hidup tanpa menghubungkannya dengan proses peredaran darah. 
Sub konsep pembuluh darah terdapat pada soal nomor 3, 4 dan 5. Menurut Sukamti (2016) pembuluh nadi berfungsi mengalirkan darah dari jantung sedangkan pembuluh balik mengalirkan darah ke jantung. Akan tetapi, banyak siswa yang mengalami miskonsepsi karena tidak bisa membedakan ciri pembuluh nadi dan pembuluh balik.

Pada sub konsep hubungan aktivitas manusia sebagian besar siswa menjawab benar yaitu berlari yang memiliki frekuensi denyut nadi paling cepat. Akan tetapi banyak siswa yang tidak bisa menjelaskan alasannya dengan tepat. Menurut Setiadi (2020) pada saat jantung berkontraksi maka terjadi peningkatan denyut nadi di arteri. Siswa menganggap bahwa detak jantung semakin cepat itu karena mengikuti pernapasan.

Siswa yang mengalami miskonsepsi pada sub konsep proses peredaran darah besar yaitu S1 dan S2. Sistem peredaran darah besar yaitu darah yang banyak mengandung oksigen (02) mengalir dari bilik kiri jantung ke seluruh tubuh (kecuali paru-paru) melalui arteri besar (aorta). Selanjutnya, terjadi pertukaran darah yang banyak mengandung oksigen dengan darah yang banyak mengandung karbon dioksida di seluruh tubuh. Darah yang banyak mengandung karbondioksida kembali ke jantung melalui vena ke serambi kanan (Wardhani, 2020). Kedua siswa yang mengalami miskonsepsi masih kebingungan dalam mengurutkan proses peredaran darah besar karena kurang memahami konsep dasarnya.

Pada konsep gangguan peredaran darah manusia ada siswa yang mengalami miskonsepsi sebagian dan miskonsepsi seluruhnya. Menurut Setiadi (2020) Anemia disebabkan rendahnya kadar hemoglobin dalam darah sehingga terjadi penurunan kapasitas sel darah merah dalam mengikat oksigen. Siswa mengalami miskonsepsi sebagian karena menjawab benar yaitu anemia, namun mengalami kesalahan dalam menjelaskan faktor yang mengakibatkan anemia. Sedangkan siswa lainnya menyamakan gejala penyakit anemia dengan penyakit lainnya.

Siswa yang mengalami miskonsepsi pada konsep cara memelihara kesehatan organ peredaran darah manusia dikarenakan hanya menjelaskan manfaat olahraga secara umum, bukan manfaat bagi peredaran darah. Menurut Alim (2012) pada saat berolahraga, kerja jantung akan meningkat karena memompa darah lebih banyak sehingga peredaran darah dan distribusi oksigen ke bagian tubuh yang membutuhkan menjadi lancar. Siswa yang lainnya mengalami miskonsepsi sebagian karena sudah memahami konsep dasar bahwa saat berolahraga dan badan kita bergerak maka peredaran darah akan lancar. Akan tetapi S1 belum bisa memberikan penjelasan ilmiahnya.

\section{Simpulan}

Pada konsep organ peredaran darah manusia, siswa banyak mengalami miskonsepsi pada konsep fungsi ruang jantung dan sifat pembuluh darah. Siswa sulit membedakan antara fungsi bilik dan serambi. Dalam sub konsep hubungan organ paru-paru dalam sistem peredaran darah, siswa juga mengalami miskonsepsi karena tidak dapat menghubungkan antara konsep pernapasan dan peredaran darah. Selain itu, siswa juga mengalami miskonsepsi karena kurang memahami sifat pembuluh nadi dan pembuluh balik. Pada konsep proses peredaran darah, siswa mengalami miskonsepsi dalam menyebutkan proses peredaran darah besar dan proses peredaran darah kecil secara urut. Hal ini disebabkan karena siswa masih belum memahami konsep dasar mengenai fungsi organ peredaran darah. Sebagian siswa juga menganggap bahwa peredaran darah besar itu dari jantung ke tubuh dan ke paru-paru. Pada konsep gangguan peredaran darah manusia, siswa mengalami miskonsepsi karena 
menyamakan gejala penyakit anemia dengan penyakit lainnya. Siswa cenderung menjawab berdasarkan apa yang diketahuinya pada kehidupan sehari-hari, tanpa mengetahui konsep yang sebenarnya. Pada konsep cara memelihara kesehatan organ peredaran darah, siswa mengalami miskonsepsi karena menjawab manfaat olahraga bagi kesehatan tubuh secara umum. Siswa belum bisa menjelaskan manfaat olahraga bagi peredaran darah berdasarkan konsep ilmiahnya.

\section{Daftar Rujukan}

Alim, A. (2012). Pengaruh olahraga terprogram terhadap tekanan darah dan daya tahan kardiorespirasi pada atlet pelatda sleman cabang tenis lapangan. Medikora, (2).

Peraturan Menteri Pendidikan dan Kebudayaan No 37 Tahun 2018 Tentang Perubahan Atas Peraturan Menteri Pendidikan Dan Kebudayaan Nomor 24 Tahun 2016 Tentang Kompetensi Inti Dan Kompetensi Dasar Pelajaran Pada Kurikulum 2013 Pada Pendidikan Dasar Dan Pendidikan Menengah

Sari, D. O. (2018). Analisis Miskonsepsi IPA Materi Sistem Pencernaan Menggunakan Certainty Of Response Index (CRI) pada Siswa kelas VSD.

Setiadi, H. (2020). Sistem Peredaran Darah Pengayaan Materi IPA SD. Bandung: SEAMEO QITEP in Science.

Subekti, A. (2017). Buku Siswa Kelas V Tema 4 Sehat itu Penting Edisi Revisi. Jakarta: Kementerian Pendidikan dan Kebudayaan.

Sukamti. (2016). Anatomi Tubuh Manusia. Malang: Universitas Negeri Malang.

Syarafina, S., Mustofa, Z. \& Prayitno, T.A., (2020). Penerapan Soal Four Tier untuk Mengidentifikasi Miskonsepsi Siswa pada Materi Aktivitas Jantung dan Pembuluh Darah. BIOSFER: Jurnal Biologi dan Pendidikan Biologi, 5(1), 6-13.

Wardani, I. S. (2017). Identifikasi Miskonsepsi Siswa Terhadap Konsep-Konsep IPA Biologi Sekolah Dasar. Surabaya: Universitas PGRI Adi Buana Surabaya.

Wisudawati, W. \& Sulistyowati, E. (2014). Metodologi Pembelajaran IPA. Jakarta: PT Bumi Aksara 